\title{
Use of Mouthguard Rates among Athletes during 2009 IIHF Word U18 Championship
}

\author{
Duymus $\mathbf{Z Y}^{*}$, Gungor $\mathrm{H}$ and Erhan SE
}

Department of Prosthodontics, Faculty of Dentistry, Atatürk University, Erzurum, Turkey

\begin{abstract}
The purpose of this study was to determine the attitudes of mouthguard users in the 2009 International Ice Hockey Federation (IIHF) Word U18 Championship Div. III Group B Turkey. The participants' appreciation in the use of protective devices, such as mouthguards, during sport activities was also evaluated. In this study a 10-item questionnaire was distributed to 82 athletes of ice hockey in 2009 IIHF Word U18 Championship. The Championship composed of 4 national teams [Bulgaria (Bul), Ireland (Irl), Iceland (IsI) and Turkey (Tur)]. Of all players were males and there average ages were Bul. 16.55, Irl.16.2, Isl. 17.0, Tur. 17.3. The result of questionnaires indicated that none of the athletes used mouthguards while participating in sports. The use of mouthguards is rare in sports, because all of athletes wear helmets and face masks associated with their helmets. IIHF rules required that athletes, who fewer than 18 years, should wear face masks during sport activities, but not mandatory of wearing mouth guards. Thesame10item questionnaire was distributed to 16 athletes of national ice hockey team of Turkey. Athletes, who are older than 18 years, usually wear not face masks but wear helmets and mouthguards. There sportsmen's $25 \%$ used mouthguards while participating in sports, but this number is not enough. Doctors and dentists need to recommend a more intensive education of athletes in sports medicine and sports dentistry.
\end{abstract}

Keywords: Mouth guard; Orofacial injury; Ice hockey

\section{Introduction}

Dental injuries are the most common type of orofacial injury sustained during participation in sports [1-3]. The current public popularity of contact sports and the willingness to take high risks in sport have led to an increase in sport injuries [4-8]. Sporting accidents are one of the most common causes of facial injuries. Studies on large groups have shown that sports account for $31 \%$ of such trauma in adults and children $[9,10]$. When the face and head are involved, this often results in tooth or mouth trauma. A blow to the face can not only cause tooth or soft tissue injuries, but can also result in fractures of the jaw or facial bones, or even cerebral damage. The subsequent esthetic, functional, psychological, and economic impact (often with high follow-up costs) demonstrate the importance of prevention. Different studies have demonstrated that wearing a mouthguard can significantly reduce the incidence of orofacial injuries [4,11-15]. Athletic mouthguards were used extensively for the prevention of intraoral trauma in sports $[16,17]$. The increasing popularity of all sporting events results in an increased potential for injuries across a wide range of both organized and unorganized sports $[18,19]$. Since the 1950s, mouthguards have been mandated in US American football at high school and college levels. In 1962 the National Alliance Football Rules Committee enacted a rule to mandate the use of facemasks and mouthguards for the first time for football players in high school and junior college. Heintz reported that in the US this regulation has significantly reduced the rate of orofacial injuries [11]. The National Collegiate Athletic Association mandated a similar rule in 1973 [20]. Josell and Abrams [21] report that mouthguards may help prevent concussion, cerebral hemorrhage, and possibly death, by separating the jaws, and thus preventing the mandibular condyles from being displaced upward and backward against the wall of the glenoid fossa. Other protective roles of mouthguards are:

1- Preventing tongue, lips and cheeks from laceration against the teeth;

2- Lessening the risk of injury to anterior teeth following a frontal blow;

3- Lessening the risk to posterior teeth of either arch [22]. Johnsen and Winters [16] report that while protecting against injuries, mouthguards may have disadvantages.

1- Comfort: they may be uncomfortable because of improper fit;

2- Tissue reactions: because of either improper fit or as a result of a traumatic blow to the oral cavity, there can be tissue reactions. However, the severity of the injury may be even worse without a mouthguard in place.

3- Function and maintenance: mouthguards can impair normal breathing and normal speech, or restrict the intake of fluids. Ranalli and Lancaster $[23,24]$ report that despite growing evidence in favor of the importance of mouthguards in injury prevention, agreement to its recommended mandatory use in sports is not universal.

Attitudes of coaches, officials, parents, and players toward wearing mouthguards influence their usage. Studies reveal that coaches are the individuals with the highest impact on whether or not players wear mouthguards. Duymuş and Güngör [25] report that none of the students of these Turkish coaches use mouthguards during sport activities. The purpose of the present study was to determine the extent of mouthguard use, as well as the frequency of oral trauma in these athletes.

\section{Materials and Methods}

The aim of this study was to determine the attitudes of mouthguard

*Corresponding author: Zeynep Yeşil Duymuş, Atatürk Üniversitesi, Diş Hekimliğ Fakültesi, Protetik Diş Tedavisi Anabilim Dalı, Erzurum, Türkiye (Turkey), Tel: 90 442 2311781; Fax: 90442 2360945; E-mail: zyesilz@hotmail.com

Received December 31, 2013; Accepted December 31, 2013; Published January 02, 2014

Citation: Duymus ZY, Gungor H, Erhan SE (2014) Use of Mouthguard Rates among Athletes during 2009 IIHF Word U18 Championship. Dentistry 4: 195. doi:10.4172/2161-1122.1000195

Copyright: $\odot 2014$ Habashneh RA. This is an open-access article distributed under the terms of the Creative Commons Attribution License, which permits unrestricted use, distribution, and reproduction in any medium, provided the original author and source are credited. 
users in the IIHF World U18 Championship Div. III Group B Erzurum in Turkey on 09-15 March 2009. In this study a 10-item questionnaire was distributed to 82 athletes of ice hockey in 2009 IIHF Word U18 Championship. The study not only consisted of 82 athletes of ice hockey in 2009 IIHF Word U18 Championship but also consisted of 16 athletes of ice hockey all of whom were selected from national ice hockey team of Turkey when they camp out in Erzurum on March 2009. These athletes were answered same questions. The Championship composed of 4 national teams [Bulgaria (Bul), Ireland (Irl), Iceland (Icl) and Turkey (Tur)]. Interviews were conducted with 82 athletes of ice hockey who are youngerthan 18 years and 16 athletes of ice hockey who upper than 18 years. Table 1 represents the athletes' questionnaire which was developed from previous surveys [18,25-28].

\section{Results}

Interviews were conducted with 82 ice hockey athletes on Bul., Irl., Isl. and Tur. U18 national teams. Of all players were males and there average ages were Bul. 16.55, Irl. 16.2, Isl. 17.0, Tur. 17.3. Each athlete was asked a series of questions concerning the use of a mouthguard, whether a mouthguard was owned, and any history of oral trauma while participating in sports. Positive responses prior to trauma were qualified concerning the type and location of the injury. Because none of the athletes who fewer than 18 years have a mouthguard, the athletes

\begin{tabular}{|l|}
\hline Name: \\
\hline Surname: \\
\hline Age: \\
\hline 1. What sports do you participate? \\
\hline 2. Did you practice as a professional athlete or amateur? \\
\hline Professional \\
\hline Amateur \\
\hline 3. Do you wear a mouth guard? \\
\hline Yes \\
\hline No \\
\hline 4. If yes, which type of mouthguard do you own? \\
\hline Stock \\
\hline Mouth-formed \\
\hline Custom-fabricated \\
\hline 5. If you have a mouthguard when do you use it? \\
\hline Games only \\
\hline Games and exercises \\
\hline 6. Have you suffered any kind of dental trauma during sport activities? \\
\hline Yes \\
\hline No \\
\hline What kind of? \\
\hline .... \\
\hline 7. If you had, were you wearing a mouthguard at that time? \\
\hline Yes \\
\hline No \\
\hline 8. Do you have any complaints while using a mouthguard? What kind of? \\
\hline Speech \\
\hline Breathing \\
\hline . Dry mouth \\
\hline Bad taste and odor \\
\hline Nausea \\
\hline Other ... \\
\hline No \\
\hline
\end{tabular}

Table 1: Questionnaire for athletes.

\begin{tabular}{|c|c|c|c|c|}
\hline Teams & Players & Average Years & Use of Mouth guard & Dental Trauma \\
\hline Bulgaria & 20 & 16.55 & 0 & 0 \\
\hline Ireland & 20 & 16.20 & 0 & 0 \\
\hline Iceland & 22 & 17.00 & 0 & 0 \\
\hline Turkey & 20 & 17.30 & 0 & 0 \\
\hline
\end{tabular}

Table 2: Distribution of players, average years and dental trauma.

were not asked whether they had any complaints while wearing the mouthguards. The participants' use of a mouthguard during games was also encouraged. Results Table 2 shows the teams, distribution of athletes, average years and dental trauma of athletes. All of them were males. None of them had used a mouthguard and suffered any orofacial injury in this championship. The use of mouthguards is rare in sports, because all of athletes wear helmets and face masks associated with their helmets. IIHF rules required that athletes, who fewer than 18 years, should wear face masks during sport activities, but not compulsion of wearing mouthguards. Athletes, who upper than 18 years, usually wear not face masks but wear helmets and mouth guards. The results of the Athletes', who are older than 18 years, questionnaires are given in Table 3. Average year of sportsmen is 20.94 and their $25 \%$ used mouth guards while participating in sports. All of types of mouth guards are mouthformed mouth guard. All of them were males.

\section{Discussion}

Injuries to the orofacial area often mean lifelong squeal with considerable follow-up costs. Different studies have shown that such injuries could be prevented by wearing a mouthguard [6,26-29]. Stenger et al. [30] reported that in football, with the introduction of face masks, dental injuries were reduced to almost half (50\%) and with the addition of mouthguards the number of dental injuries in this sport decreased to $1.4 \%$. The present study examined the type and frequency of orofacial injuries and the use of mouthguards by ice hockey athletes in the 2009 IIHF Word U18 Championship. Furthermore, the attitude of officials towards the use of mouthguards was analyzed. In line with previous studies $[14,31,32]$, there are large variations between the different sports concerning the acceptance of wearing a mouthguard.

Although over $40 \%$ of all players approved the use of a mouthguard, none actually used one. The most common injuries reported were soft tissue lacerations and tooth fractures. Surprisingly in soccer, cerebral concussion was a common finding. The use of mouthguards as a necessity in soccer, despite the relatively low rate of orofacial injuries, remains a controversial issue. In fact, the study by Labella et al. [33] could not show any differences in the concussion rate of basketball players with or without mouthguards. The orofacial trauma rate in this study group was $0 \%$. Further research is needed to determine the risk of orofacial injury in all contact sports in Turkey. In the present survey, it was found that the level of usage, knowledge, and awareness regarding the benefits of using mouthguards in this championship are minimal. IIHF and other all federations of contact sports should be required to wear mouthguard for athletes. Dentists as well as other healthcare professionals should educate players and his parents in order to promote the use of mouthguards in professional and amateur sports, especially for adolescents. Dental professionals, especially pediatric dentists, should regularly question patients' parents about sports participation and inform them about orofacial injury risk and suggest the use of a mouthguard.

\section{Conclusion}

The study showed that the majority of ice hockey athletes agree on the benefits of mouthguards but their knowledge is limited. Likewise, 
Citation: Duymus ZY, Gungor H, Erhan SE (2014) Use of Mouthguard Rates among Athletes during 2009 IIHF Word U18 Championship. Dentistry 4: 195. doi:10.4172/2161-1122.1000195

\begin{tabular}{|l|c|c|}
\hline & $\mathrm{n}$ & $(\%)$ \\
\hline The rate of using a mouth guard & 4 & 25 \\
Yes & 12 & 75 \\
\hline No & & \\
\hline The type of mouth guard & 0 & 0 \\
\hline Stock & 4 & 100 \\
Mouth-formed & 0 & 0 \\
\hline Custom-fabricated & & \\
\hline The rate of dental trauma & 10 & 62.5 \\
Yes & 6 & 37.5 \\
\hline No & 6 & 100 \\
\hline The rate of professional athletes & 0 & 0 \\
\hline The rate of amateur athletes & 13 & 81.25 \\
\hline The type of the orofacial injuries & 3 & 18.75 \\
\hline Soft tissue injuries & & \\
\hline Teeth injuries & & \\
\hline
\end{tabular}

Table 3: Distribution of the athletes, who were upper than 18 years, answers to the interview.

these athletes do not use mouthguards and they do not have much information about professionally fitted mouthguards. These athletes cerebrated that the using of face mask protection to dental injuries during sports. Face mask maybe protection to dental injuries but using of mouth guard is increased the protection of intra-oral injuries. It was concluded that the use of mouthguards during professional or amateur sport activities should be promoted.

\section{References}

1. Chapman PJ (1986) Prevention of orofacial injuries in children and young adolescents. Aust Med Sport 18: 3-6.

2. Braham RL, Roberts MW, Morris ME (1977) Management of dental trauma in children and adolescents. J Traumatol 17: 857-865.

3. Davis GT, Knott SC (1984) Dental trauma in Australia. Aust Dent J 29: 217-221.

4. Flanders RA, Bhat M (1995) The incidence of orofacial injuries in sports: a pilot study in Illinois. J Am Dent Assoc 126: 491-496.

5. Jennings DC (1990) Injuries sustained by users and non-users of gum shields in local rugby union. Br J Sports Med 24: 159-165.

6. Kerr IL (1986) Mouth guards for the prevention of injuries in contact sports. Sports Med 3: 415-427.

7. Padilla R, Balikov S (1993) Sports dentistry: coming of age in the 90s. J Calif Dent Assoc 21: 36-37.

8. Smith WS, Kracher CM (1998) Sports-related dental injuries and sports dentistry. Dent Assist 67: 12-16.

9. Gassner R, Tuli T, Hachl O, Rudisch A, Ulmer H (2003) Craniomaxillofacial trauma: a 10 year review of 9,543 cases with 21,067 injuries. J Craniomaxillofac Surg 31: 51-61.

10. Gassner R, Tuli T, Hachl O, Moreira R, Ulmer H (2004) Craniomaxillofacia trauma in children: a review of 3,385 cases with 6,060 injuries in 10 years. J Oral Maxillofac Surg 62: 399-407.

11. Heintz WD (1975) The case for mandatory mouth protectors. Physician Sports Med 3: 61-63.

12. Morrow RM, Bonci T (1989) A survey of oral injuries in female college and university athletes. Athletic Training 24: 236-237.

13. Morrow RM, Bonci T, Seals RR, Branwell GM (1991) Oral injuries in southwest conference women basketball players. Athletic Training 26: 344-345.

14. Yamada T, Sawaki Y, Tomida S, Tohnai I, Ueda M (1998) Oral injury and mouthguard usage by athletes in Japan. Endod Dent Traumatol 14: 84-87.

15. Woodmansey KF (1997) Athletic mouth guards prevent orofacial injuries. J Am Coll Health 45: 179-182.
16. Johnsen DC, Winters JE (1991) Prevention of intraoral trauma in sports. Dent Clin North Am 35: 657-666.

17. Ranalli DN (2002) Sports dentistry and dental traumatology. Dent Traumatol 18: $231-236$

18. Onyeaso CO, Adegbesan OA (2003) Knowledge and attitudes of coaches of secondary school athletes in Ibadan, Nigeria regarding oro-facial injuries and mouthguard use by the athletes. Dent Traumatol 19: 204-208.

19. Takeda T, Ishigami K, Ogawa T, Nakajima K, Shibusawa M, et al. (2004) Are all mouthguards the same and safe to use? The influence of occlusal supporting mouthguards in decreasing bone distortion and fractures Dent Traumatol 20: 150-156.

20. Powers JM, Godwin WC, Heintz WD (1984) Mouth protectors and sports team dentists. Bureau of Health Education and audiovisual Services, Council on Dental Materials, Instruments, and Equipment. J Am Dent Assoc 109: 84-87.

21. Josell SD, Abrams RG (1982) Traumatic injuries to the dentition and its supporting structures. Pediatr Clin North Am 29: 717-743.

22. National Health and Medical Research Council Mouth guard Statement 108th Session (1989) Canberra: Canberra National Health and Medical Research Council.

23. Ranalli DN, Lancaster DM (1995) Attitudes of college football coaches regarding NCAA mouthguard regulations and player compliance. J Public Health Dent 55: 139-142.

24. Ranalli DN, Lancaster DM (1993) Attitudes of college football officials regarding NCAA mouthguard regulations and player compliance. J Public Health Dent 53: $96-100$.

25. Duymuş ZY, Güngör H (2009) Use of mouthguard rates among university athletes during sport activities in Erzurum, Turkey. Dent Traumatol 25: 318-322.

26. Çetinbaş T, Sönmez H (2006) Mouth guard utilization rates during sport activities in Ankara, Turkey. Dent Traumatol 22: 127-132.

27. McNutt T, Shannon SW, Wright JT, Feinstein RA (1989) Oral trauma in adolescent athletes: a study of mouth protectors. Pediatr Dent 11: 209-213.

28. Lieger O, von Arx T (2006) Orofacial/cerebral injuries and the use of mouthguards by professional athletes in Switzerland. Dent Traumatol 22: 1-6.

29. Seals RR Jr, Morrow RM, Kuebker WA, Farney WD (1985) An evaluation of mouthguard programs in Texas high school football. J Am Dent Assoc 110: 904-909.

30. Stenger JM, Lawson EA, Wright JM, Ricketts J (1964) Mouth guards: protection against shock to head, neck and teeth. J Am Dent Assoc 69: 273-282.

31. Tschan JD, Rothlisberger B, Hegg I, von Arx T (2003) Frequency and nature of anterior tooth injuries and the use of mouth protectors in sport clubs in Bern. Schweiz Monatsschr Zahnmed 113: 20-26.

32. Ferrari $\mathrm{CH}$, Ferreria de Mederios JM (2002) Dental trauma and level of information: mouth guard use in different contact sports. Dent Traumatol 18: 144-147.

33. Labella CR, Smith BW, Sigurdsson A (2002) Effect of mouth guards on denta injuries and concussions in college basketball. Med Sci Sports Exerc 34: 41-44. 